\title{
GFRA2 Gene
}

National Cancer Institute

\section{Source}

National Cancer Institute. GFRA2 Gene. NCI Thesaurus. Code C24428.

This gene plays a regulatory role in neuronal survival and differentiation. 